\title{
MAKNA PENTING KEBERADAAN KOMUNITAS POLITIK KEAMANAN ASEAN DALAM MENYELESAIKAN KONFLIK KAWASAN
}

\author{
Hendra Maujana Saragih ${ }^{1}$,Yanyan Mochamad Yani ${ }^{2}$ \\ ${ }^{1}$ Program Studi Ilmu Hubungan Internasional, Universitas Nasional \\ ${ }^{2}$ Program Studi Pascasarjana, Universitas Padjadjaran, Bandung \\ email : hendramaujana@gmail.com,yan2m@hotmail.com
}

Korespondensi : hendramaujana@gmail.com

\begin{abstract}
This paper seeks to emphasize that ASEAN's strategic position in the Southeast Asian region, which has never used military and armed forces in resolving conflicts between members of ASEAN or outside ASEAN Members and this is ASEAN's greatest achievement in regulating peaceful interactions within the region. The development and formation of the ASEAN security posture in the form of a Security Political Community are certainly expected to play a large role in the framework of becoming the forefront of ASEAN in the effort to improve relations that have been torn apart by the conflict and to re-knit it to be more peaceful and set an example for other regions.
\end{abstract}

Keywords: regional security, effectiveness, region, conflic, political community

\begin{abstract}
Abstrak
Makalah ini berupaya menegaskan bahwa posisi strategis ASEAN di kawasan Asia Tenggara yang tidak pernah menggunakan kekuatan militer dan bersenjata dalam menyelesaikan konflik baik antar sesama anggota ASEAN ataupun di luar Anggota ASEAN dan ini merupakan prestasi terbesar ASEAN dalam mengatur interaksi damai di dalam kawasan. Pembangunan dan pembentukan postur keamanan ASEAN yang berbentuk Komunitas Politik keamanan tentunya diharapkan akan banyak berperan dalam rangka menjadi garda terdepan ASEAN dalam upaya memperbaiki relasi-relasi yang sudah tercabik akibat konflik yang pernah terjadi dan merajutnya kembali agar lebih damai dan menjadi contoh bagi kawasan lainnya.
\end{abstract}

Kata kunci: keamanan regional, efektifitas, kawasan, konflik, komunitas politik

\section{PENDAHULUAN}

\section{Latar Belakang}

Perkembangan Pembangunan postur keamanan ASEAN dalam bentuk Asean Political Security Community di kawasan Asia Tenggara penanda sejarah baru akan eksistensi kawasan ini dalam memikirkan postur ideal dan bisa dimplementasikan oleh anggotanya. Tentunya pembangunan postur ini membawa berbagai macam isu baru dan mekanisme baru juga yang boleh jadi mempunyai 
pengaruh langsung atau tidak langsung dalam segala pengambilan keputusan yang harus dijalankan oleh ASEAN. Dengan adanya postur ini maka isu-isu penting utamanya persepsi ancaman keamanan dan konflik akan menjadi bahasan serius dalam komunitas ini. Persepsi ancaman keamanan dan konflik baik yang datang dari Negara anggota ataupun luar kawasan sejatinya juga dapat dirumuskan dan ditetapkan bersama agar Negara anggota mempunyai batasan mengerti betul keberadaan postur yang diharapakan eksis dan running tahun 2025.

Diantara konflik yang masih ada dapat dicatat adalah konflik teritorial baik antar sesama Negara anggota ASEAN atau anggota ASEAN dengan Negara di luar kawasan. Konflik budaya juga menjadi sorotan penting dalam potret kondisi obyektif kawasan. Konflik teritorial yamng masih terus berlanjut yaitu Konflik Thailand - Kamboja yang mana Mahkamah Internasional memutuskan bahwa Kamboja sebagai pemilik Kuil Preah Vihear dan akibatnya Thailand harus menarik pasukan militernya maupun para penjaga yang dikerahkan di sekitar kuil atau disekitar wilayah kedaulatan Kamboja. Keputusan Mahkamah Internasional tersebut adalah bersifat mengikat dan final artinya para pihak yang bersengketa di hadapan Mahkamah Internasional tidak dapat melakukan banding atas putusan yang telah dikeluarkan. Mahkamah Internasional mendasarkan putusannya pada peta yang dibuat sekelompok ahli yang dibentuk atas kesepakatan antara Pemerintah Perancis dan Pemerintah Siam, yaitu the Commission of Delimitation. Dalam putusannya, Mahkamah Internasional tidak dengan tegas menetapkan garis batas kedua negara. Mahkamah Internasional hanya menetapkan siapa yang memiliki kedaulatan atas kuil tersebut (Sari, 2008).

Pada bulan Juli 2008 Kuil Preah Vihear yang diperkirakan yang telah berumur 900 tahun dimasukkan dalam daftar warisan budaya dunia (Word Heritage List) oleh UNESCO. Hal ini disambut gembira oleh Pemerintah Kamboja, namun memicu masalah di Thailand (Sinar Harapan, 7 Oktober 2008). Akibatnya, terjadilah kontak senjata antara tentara militer Kamboja dengan tentara militer Thailand di perbatasan dekat Kuil Preah Vihear yang menjadi jantung sengketa antara kedua negara. Baku tembak yang pecah antara tentara militer kedua negara terjadi pada tanggal 15 Oktober 2008 yang mengakibatkan tewasnya dua orang tentara Kamboja dan melukai lima orang tentara Thailand, dan kemudian baku tembak untuk kedua kalinya terjadi pada tanggal 3 April 2009, akibat kontak senjata tersebut telah menewaskan dua orang tentara militer Thailand dan mengakibatkan sepuluh orang tentara militer lainnya mengalami luka-luka (Sari, 2008).

Konflik territorial lainnya adalah antara Vietnam Kamboja yang mana latar belakang awal kemunculan konflik di Kamboja dipengaruhi oleh beberapa faktor. Faktor pertama bahwa adanya berbagai kepentingan dari pihak asing di Kamboja. Pihak asing yang terlibat dalam proses pembentukan bangsa Kamboja ini cenderung mengambil keuntungan dari Kamboja. Kamboja merupakan negara yang terletak di bagian timur laut Asia Tenggara dan merupakan negara yang berbatasan langsung dengan Thailand, Vietnam, dan Laos. Sekitar abad ke-10 sampai abad ke-14, wilayah Kamboja berada di bawah kejayaan Kerajaan Khmer. Namun, sejak abad ke-14, Thailand dan Vietnam menginvasi dan berusaha untuk menguasai Kamboja terus menerus selama 4 abad. Thailand melihat bahwa Kamboja memiliki pangsa 
pasar yang sangat potensial bagi perdagangan kedua negara tersebut. Vietnam kemudian ingin menyatukan wilayah Indocina di bawah kepemimpinannya yang didukung oleh Perancis. Kamboja kemudian menjadi bagian dari French Protectorate atau perlindungan Perancis dan bagian dari French Indochina atau bagian dari koloni Perancis. Awal tahun 1940-an, tepatnya pada saat Perang Dunia II, Kamboja menjadi wilayah perebutan bagi Perancis dan Jepang. Jepang berhasil merebut Kamboja dari perancis pada tahun 1940, tetapi kemudian kembali menjadi wilayah perlindungan Perancis sampai tahun 1953 karena Jepang yang menyerah pada sekutu. Negara superpower seperti Amerika Serikat, Uni Soviet dan Cina juga memliki kepentingan terhadap Kamboja, di mana Cina memberikan dukungan kepada pemerintahan Democratic Kampuchea di bawah pimpinan Pol Pot dan Pangeran Sihanouk untuk mengusir Vietnam yang didukung oleh Uni Soviet untuk keluar dari Kamboja. Sedangkan, Amerika Serikat melihat Kamboja sebagai wilayah yang strategis untuk membendung komunisme Vietnam Utara pada Perang Indocina tahun 1965-1975 dengan jalan membangun aliansi dengan negara-negara kawasan Indocina seperti Vietnam Selatan, Thailand dan Kamboja di bawah pemerintahan Lon Nol (Runtukahu, 2009).

Faktor kedua yaitu adanya implikasi kebijakan rezim Pol Pot yang menyebabkan konflik berkepanjangan di Kamboja. Sebagai tindakan awal, Pol Pot membagi masyarakat di Kamboja menjadi 5 kategori yakni petani, pekerja, borjuis, kapitalis dan feudalis sehingga kebijakan-kebijakan yang ditetapkan kemudian mengubah seluruh elemen masyarakat di Kamboja. Kebijakan-kebijakan yang diterapkan oleh rezim Pol Pot tersebut kemudian mengundang berbagai reaksi antara negara-negara sekitarnya. Reaksi yang cukup keras disampaikan oleh Vietnam bahwa Vietnam merasa kebijakan rezim Pol Pot telah merugikan warga keturunan Vietnam di Kamboja. Akibatnya, terjadilah intervensi Vietnam di Kamboja sebagai akar dari konflik di Kamboja. Tindakan Vietnam yang melakukan intervensi didasari atas perlakuan tidak manusiawi yang dilakukan oleh rezim Pol Pot terhadap puluhan ribu warga keturunan Vietnam dan khususnya para anggota partai komunis pro Vietnam yang juga pernah berkoalisi menumbangkan Lon Nol pada tahun 1975. Tindakan tersebut dianggap Vietnam telah melewati batas toleransi pihak Vietnam sehingga Vietnam merasa terpaksa untuk menyerang pemerintahan Pol Pot guna menyelamatkan rakyatnya (Runtukahu, 2009).

Pada awal tahun 1979, inervensi Vietnam secara resmi mengambil alih pemerintahan di Kamboja dan kemudian membangun negara boneka Vietnam di Kamboja. Vietnam yang berhasil mengambil alih Kamboja membentuk pemerintahan baru yang dikenal sebagai People's Republic of Kampuchea (PRK) yang dipimpin oleh Presiden Heng Samrin dan Hun sen sebagai Perdana Menteri. Berdirinya PRK sebagai pemimpin Kamboja mendapat dukungan dari Uni Soviet dan Laos. Namun, PRK gagal untuk mendapatkan dukungan dari dunia internasional khususya PBB. Hal ini disebabkan oleh intervensi militer yang dilakukan Vietnam mengundang reaksi negatif dari dunia internasional. PBB dan kebanyakan negara lainnya menolak untuk mengakui rezim Heng Samrin sebagai pemerintahan yang sah di Kamboja (Runtukahu, 2009). 
Sengketa Laut Cina Selatan pun juga menjadi isu besar di negara anggota ASEAN yang mana melibatkan banyak negara sehingga penyelesaiannya menjadi sangat rumit dan berlangsung berlarut-larut. Sengketa ini juga mempunyai latar belakang yang cukup rumit sehingga belum terjadi kesepakatan diantara negaranegara bersengketa.Kepulauan Spratly terletak dikelilingi oleh beberapa negara yaitu, Indonesia, Malaysia, Vietnam, Brunei Darussalam, Cina, Taiwan, dan Filipina. Kepulauan Spratly pada awalnya adalah sebuah pulau yang tidak berpenghuni dan sebenarnya bukan merupakan yang layak huni. Hal ini disebabkan kebanyakan pulau ini hanyalah berupa gugusan karang-karang laut. Namun klaim wilayah kepemilikan terhadap kepulauan Spratly mulai bermunculan karena kepulauan Spratly ini mempunyai banyak potensi keuntungan sumber daya alamseperti kandungan minyak yang melimpah dan letak kepulauan spratly yang strategis. Selain kandungan minyak yang melimpah, terdapat pula kandungan gas alam yang ada di wilayah Laut Cina Selatan. Kekayaan alam yang dimiliki membuat beberapa negara yang bersengketa atas wilayah kepulauan Spratly ini bersikeras untuk mengakui dan mengklaim atas wilayah tersebut. Kawasan kepulauan Spratly ini juga merupakan kawasan yang terletak di lintasan laut yang strategis karena berada di lintas layar dan perdagangan antar negara. Faktor ini juga kemudian menjadi faktor pendukung negara-negara yang bersengketa untuk semakin bernafsu mengklaim atas kepulauan Spratly ini, karena siapapun yang resmi memiliki kepulauan Spratly ini, maka negaranya akan memperoleh keuntungan ekonomi dari hasil kapal-kapal yang melewati dan melintasi kepulauan spratly untuk melakukan. Sebagai salah satu perairan paling sibuk di dunia, tentunya membawa keuntungan bagi negara-negara yang wilayah lautnya dilewati (Nugraha, 2012).

Lain lagi dengan Konflik Teluk Bengal terjadi antara negara Myanmar, yang terletak di Asia Tenggara dan negara Bangladesh yang terletak di Asia Selatan. Latar belakang terjadinya hal ini dikarenakan belum adanya kesepakatan garis batas landas kontinen antara dua negara tersebut. Hal tersebut diperparah dengan, eksploitasi minyak yang dilakukan oleh Myanmar di perairan Teluk Benggala, tanpa persetujuan dari Bangladesh. Sehingga konflik Myanmar dan Bangladesh ini dilatar belakangi oleh sengketa sebidang wilayah yaitu teluk Benggala yang terletak dalam perairan sepanjang tepi barat Myanmar dan sekitar $93 \mathrm{~km}$ barat daya pulau St. Martin.Atau jika ditarik lebih jauh, ketegangan antara pemerintah Myanmar dan Bangladesh berpusat pada sengketa cadangan minyak yang akan dieksploitasi dan belum disepakatinya perbatasan teritorial ini. Konflik perbatasan ini, semakin menambah daftar panjang konflik yang terjadi di Asia Tenggara. Wilayah Asia Tenggara sebagian besar merupakan wilayah perairan, sehingga geografi maritim kain kompleks. Dalam konteks ini, bagaimanakah sesungguhnya Pembangunan Keamanan Regional ASEAN bisa Efektif Dalam Menyelesaikan Konflik Kawasan?

\section{TINJAUAN KONSEP}

Secara teoritis tulisan ini mengacu kepada Teori Regional Security Complex dan Teori Komunias Keamanan. Dalam teorinya mengenai security, Barry Buzan mengajarkan kepada kita bahwa dimensi keamanan regional sangat kontributif dalam pengembangan kajian mengenai keamanan, Buzan juga berpendapat bahwa 
keamanan adalah suatu fenomena yang mempunyai sifat relasional. Untuk itu penstudi keamanan tidak mampu memahami dan memaknai keamanan yang terjadi di suatu Negara atau kawasan tanpa mengetahui pola internasional yang memiliki saling ketergantungan atas keamanan yang berada di sekitarnya (Buzan, 1991).

Barry Buzan dalam bukunya People, State and Fear menegaskan bahwa ancaman keamanan acapkali berada di jarak dekat yang mengharuskan kerjasama keamanan dengan negara tetangga menjadi prioritas utama. Dalam mempelajari kerjasama keamanan kita tealh dikenalkan oleh Barry Buzan dua pola utama yaitu amity dan enmity. Amity adalah hubungan kerjasama antar Negara yang berlandaskan rasa pertemanan dan harapan agar mendapatkan dukungan atau perlindungan satu sama lain. Sedangkan pola enmity adalah hubungan kerjasama antar Negara yang landasannya adalah kecurigaan dan rasa takut yang faktorfaktornya adalah adalah konflik perbatasan, faktor kepentingan, faktor ideologi, etnis, serta dan faktor pendekatan sejarah yang telah terajut antar Negara. Konsep mengenai kerjasama keamanan dan faktor-faktor kepentingan antar negara membuahkan teori security complex yang oleh Buzan diposisikan sebagai " a group of states whose primary security concerns link together sufficiently closely that their national securities cannot realistically be considered apart from one another." (Buzan, 1991).

Maraknya globalisasi dan dengan mudahnya setiap negara untuk dapat terhubung lewat organisasi regionalism maka dengan mudah juga bagi penstudi hubungan internasional untuk melakukan revisi terhadap perspektif Buzan tentunya. Hal ini dapat ditelusuri dalam definisi terbaru dari Buzan yang diramu oleh Soderbaum yang menyatakan tidak hanya persepsi dan kekhawatiran yang mengitari suatu negara sajalah yang saling terikat sehingga menimbulkan regional security complex tetapi saat ini yang harus dicermati juga adalah setiap negara di suatu kawasan mengalami securitization sekaligus de-securitization dan proses ini tidak dapat dipisahkan antar negara satu dengan lainnya yang berada dalam wilayah yang sama (Soderbaum, 2003). Hal ini menkonfirmasi tentang refleksi Buzan untuk menggeser asumsinya yang sebelumnya sangat state-centric lalu memberikan ruang pada aktor lain yang dapat berupa negara, organisasi internasional, dan aktor lain. Selain itu juga Buzan melalui defininsi saat ini ingin menyatakan bahwa reginal security complex bukanlah suatu yang kondisi yang tiba-tiba ada begitu saja tetapi melalui konstruksi proses securitization.

Adapun literatur tentang komunitas keamanan merajuit ikatan antara identitas, komunitas dan keamanan. Pergumulan ide tentang komunitas keamanan telah lama dimulai sejak Karl Deutsch menghadirkan definisi awal dari komunitas keamanan dan telah juga dikembangkan pemikir-pemikir lainnya lalu membentuk kerangka analisis yang fleksibel (Vesa, 1999). Bahwa idealnya komunitas keamanan harus melindungi seluruh anggotanya dari konflik yang muncul dari ancamanancaman internal maupun eksternal. Kedua, komunitas keamanan perlu memfasilitasi terjadinya pencegahan konflik antar dan intra negara. Ketiga, komunitas keamanan harus berupaya membentuk semangat komunitas di dalam keanggotaan regional untuk menciptakan identitas bersama sehingga komunitas tersebut dapat dipandang oleh pihak luar kawasan sebagai entitas tunggal, dengan 
kata lain memiliki rasa ke-kita-an (sense of we-ness) (Bellamy dan McDonald, 2004).

Adler dan Barnet berteori bahwa pada tahap awal (nascent) muncul kebutuhan di antara negara-negara anggota untuk mengkoordinasikan kebijakankebiajakan keamanan nasional lewat organisasi internasional yang bisa mengeksplorasi kepentingan-kepentingan bersama, menciptakan aturan bersama dan mengawasi pelaksanaannya. Pada tahap ini, komunitas keamanan bisa menjadi faktor yang menghilangkan rasa takut di antara negara-negara anggota akan ancaman terhadap keselamatan nasionalnya lewat hubungan kerjasama yang merubah pola belanja pertahanan. Belanja pertahanan tidak lagi didedikasikan untuk persiapan agresi antar sesama negara anggota. Pada tahap ini pula terbentuk koalisi inti (core state) negara-negara yang merupakan fasilitator/ dinamisator dan stabilisator fase awal ini. Negara-negara ini lah yang bisa diharapkan untuk memimpin, melindungi, memodali, dan menggelorakan sense of purpose di antara negara-negara anggota lain. Pada tahap lanjut (ascendant) terjadi perubahan pola pengadaan alutsista yang menunjukkan adanya interdependensi, pertukaran intelijen dan kerja sama dan koordinasi yang lebih erat antar militer negara anggota. Pada tahap ini pula mulai muncul identitas bersama yang mendorong terwujudnya expectation for peaceful change. Akhirnya pada tahap dewasa (mature), dapat dilihat adalah "way of life" yang sama. Tata kelola regional dilakukan dengan lebih informal dan berbasis kontruksi makna yang sama untuk peristiwa atau tindakan aktor lain.

Identitas kolektif adalah gagasan sentral dalam konsep komunitas keamanan; identitas adalah komponen yang membedakan komunitas keamanan dari bentuk-bentuk arsitektur keamanan yang lain, seperti rezim keamanan atau aliansi. Salah satu penanda definitif dari terbentuknya komunitas keamanan, sesuai dengan definisi dari Karl Deutsch adalah adanya "dependable expectation of peaceful change"; ini adalah suatu kondisi yang hanya bisa dicapai dengan terbangunnya kepercayaan (trust) di antara negara-negara anggota, dan kepercayaan itu dapat dibangun bila ada "sense of we-ness" atau rasa ke-kita-an atau identitas bersama (common identity). Identitas bersama dapat dimungkinkan oleh 2 (dua) hal. Pertama, kesadaran akan adanya masalah atau ancaman yang dihadapi oleh semua negara anggota dan kebahayaan yang muncul dari perpecahan dan konflik antar sesama atau di dalam negara anggota yang berkepanjangan. Kesadaran ini lah yang merepresi konflik dan mendorong kerjasama, dan ia ditempa oleh pengalaman konflik dan kerjasama dalam waktu yang lama. Kedua, identitas bersama dapat muncul dari proses kontra-identitas (counter-distinction) dengan pihak di luar lingkaran "kita". Pada mekanisme kedua ini lah sebenarnya negara-negara besar memainkan peran.

\section{HASIL DAN PEMBAHASAN \\ Potensi Konflik Negara-Negara ASEAN}

Hingga saat ini masih ditemukan benih-benih konflik antar negara di kawasan Asia Tenggara yang mewarnai dan mempengaruhi hubungan bilateral maupun multilateralnya. Secara khusus dan sangat sensitif dan dapat menghambat 
hubungan antar Negara yaitu yang menyangkut batas wilayah yang boleh jadi dapat muncul secara tiba-tiba kepermukaan. Diantara benih-benih konflik adalah antara Malaysia dan Pilipina yang saling klaim atas Sabah, Malaysia dan Indonesia atas Pulau Sipadan dan Ligitan (kendati secara hukum internasional sudah terselesaikan) dan Ambalat, Indonesia dengan Pilipina atas Pulau Miangas, Singapura dan Malaysia atas Pulau Batu Puteh,lebih dari itu banyak kelompok rakyat Malaysia yang selalu mendesak pemerintah Malaysia untuk membekukan hubungan dengan Singapura akibat pertentangan jalur kereta api antar dua Negara tersebut.

Adapun sumber konflik yang sifatnya multilateral berada di kawasan Laut Cina Selatan. Di kawasan itu banyak Negara dikawasan Asia Tenggara kecuali Indonesia yang saling klaim yaitu Malaysia, Pilipina, Vietnam, dan Brunei Darussalam bersama-sama dengan RRC dan Taiwan, saling klaim mengenai pemilikan atar gugus-gugus pulau di Kepulauan Spratly. Hingga saat ini saling klaim di kawasan Laut Cina Selatan itu masih tetap menghangat.

Di samping masih adanya benih-benih dan sumber konflik antara negaranegara Asia Tenggara sendiri, ASEAN masih di bawah bayang-bayang invasi luar. Namun, pada saat ini terbukti bangsa-bangsa di Asia Tenggara sendiri belum punya persepsi yang sama mengenai ancaman tersebut. Indonesia selalu memproyeksikan ancaman terhadap wilayahnya datang dari utara. Meskipun tidak dinyatakan secara eksplisit, tetapi RRC-lah yang dianggap sebagai ancaman. Sebaliknya, Thailand sampai saat ini masih menganggap RRC bukan pengancam Asia Tenggara.

Sementara itu Singapura dan Malaysia punya persepsi ancaman yang lebih khusus lagi. Di samping keduanya bersaing di antara mereka sendiri, dalam batasbatas tertentu kedua negara itu masih menyimpan kekhawatiran terhadap Indonesia, akibat konfrontasi yang dijalankan Indonesia di masa lalu. Akibatnya, tidak jarang ulah Singapura dan Malaysia memancing munculnya rasa kesal pada beberapa kalangan di Indonesia; khususnya yang berkaitan dengan kerjasama pertahanan antara Singapura, Malaysia, Brunei Darussalam, Australia, Selandia Baru, dan Inggris.

Perbedaan persepsi ancaman dan banyaknya benih-benih dan potensi konflik di kawasan ini, secara khusus belum pernah dibicarakan secara regional. Sebaliknya, usaha-usaha penyelesaian masalah secara bilateral banyak yang mengalami jalan buntu, sehingga masih tetap menimbulkan rasa saling curiga di antara sesama anggota ASEAN.

\section{Pembangunan Keamanan Regional}

Komunitas keamanan ASEAN adalah suatu masyarakat yang secara khusus mengandalkan proses damai dalam menyelesaikan perselisihan yang mungkin terjadi di antara sesama anggota. Komunitas ini berpegang pada prinsip-prinsip noninterfensi, pengambilan keputusan berdasarkan mufakat, ketahanan nasional dan regional, saling menghormati kedaulatan nasional, penghindaran penggunaan ancaman ataupun penggunaan ataupun kekuatan dan penyelesaian perbedaan maupun perselisihan secara damai. Sasaran kerjasama keamanan diarahkan pada upaya-upaya menangkal persengketaan diantara sesama Negara anggota maupun 
antara Negara anggota dengan negara-negara non-ASEAN, berusaha melakukan pencegahan eskalasi persengketaan itu menjadi konflik.

ASEAN secara keseluruhan berpegang pada prinsip-prinsip keamanan komprehensif, ketahanan nasional dan regional yang memiliki aspek-aspek politik, ekonomi, sosial dan budaya. Namun, disini ASEAN tidak akan membentuk diri sebagai suatu pakta pertahanan, persekutuan militer ataupun mengembangkan suatu politik luar negeri bersama. Negara-negara ASEAN juga berpegang pada hakhaknya untuk mempertahankan eksistensi yang bebas dari campur tangan pihak luar dalam urusan internal masing-masing.

Pemahaman bahwa ASEAN menjadi komunitas keamanan lebih didasarkan pada kenyataan bahwa tidak ada satupun anggotanya yang menggunakan kekuatan bersenjata atau anggapan perlunya digunakannya kekuatan militer dalam menyelesaikan konflik di kawasan Bahwa ASEAN memang sebuah komunitas keamanan karena kemampuannya untuk mencegah konflik dari kemungkinan eskalasi konfrontasi bersenjata untuk menjadi komunitas politik,adalah kenyataan bahwa ketiadaan perang diantara negara-negara anggota ASEAN sejak organisasi tersebut didirikan tahun 1967 merupakan prestasi terbesar ASEAN dalam mengatur interaksi damai didalam kawasan. (Leifer, 1995)

Komunitas keamanan ASEAN atau ASEAN Political Security Community (APSC) pada dasarnya dibentuk sebagai upaya untuk menjaga kestabilan kawasan Asia Tenggara. Kestabilan politik dan keamanan akan menunjang sektor ekonomi sehingga mampu menciptakan kawasan yang damai sekaligus makmur. Sebaliknya, iklim ekonomi kawasan yang sehat akan menunjang stabilitas politik dan keamanan karena berkurangnya disparitas ekonomi antar negara. Secara teoritik memang tampak sederhana. Tetapi di tataran realitas, jalan menuju integrasi cukup terjal dan berliku. Ditambah lagi kenyataan bahwa ditinjau dari segi apapun, kawasan Asia Tenggara adalah kawasan yang luar biasa majemuk.

Pembentukan komunitas politik dan keamanan ASEAN merupakan suatu fenomena yang menarik karena komunitas ini dibentuk dalam suatu kawasan regional yang terdiri dari negara-negara dengan kapabilitas militer yang cenderung serupa karena tidak terdapat hegemon regional di kawasan tersebut.

Komunitas ini diharapkan bisa menurunkan intensitas konflik bahkan perang terbuka antara negara-negara ASEAN. Komunitas ini dibentuk untuk memberikan kerangka regional bagi anggotanya untuk menyelesaikan masalahmasalah keamanan dan perselisihan di dalamnya serta meningkatkan dan mempercepat kerjasama ke tingkat yang lebih tingg. Selain itu, negara-negara anggota menyadari bagaimana semakin berkembangnya ancaman keamanan transnasional yang tidak dapat diselesaikan secara unilateral. Komunitas Keamanan ini bertujuan untuk mempercepat kerjasama politik keamanan di ASEAN untuk mewujudkan perdamaian di kawasan, termasuk dengan masyarakat internasional. Komunitas ini bersifat terbuka, berdasarkan pendekatan keamanan komprehensif dan tidak ditunjukan untuk membentuk suatu pakta pertahanan/aliansi militer maupun kebijakan luar negeri bersama (common foreign policy). Komunitas ini juga mengacu kepada berbagai instrumen politik ASEAN yang telah ada seperti ASEAN Regional Forum (ARF) dengan tiga pilarnya: membangun rasa saling percaya 
(confident building measure/CBM), diplomasi preventif (Preventive Diplomacy), dan penyelesaian konflik (conflict resolution), Zone of Peace, Freedom and Neutrality (ZOPFAN), Treaty of Amity and Cooperation in Southeast Asia (TAC), dan Treaty on Southeast Asia Nuclear Weapon-Free Zone (SEANWFZ), serta menaati Piagam PBB dan prinsip-prinsip hukum internasional terkait lainnya.

\section{Penguatan Dialog Keamanan ASEAN}

Harry Harding dalam tulisannya mengenai Global Engagement : Cooperative Security in the Asia Pasific menggarisbawahi bahwa konsep cooperative security adalah konsep yang sensitif terhadap isu militer maupun nonmiliter. Harding kemudian mengangkat contoh kasus yang dianggap merupakan penerapan secara nyata dari cooperaive security yaitu forum dialog yang dikembangkan oleh ASEAN Regional Forum dan Council for Security Cooperation on Asia-Pacific (CSCAP) yang juga sebagai bagian dari ASEAN Regional Forum yang merupakan pertemuan antara first track dan second track. (Capie dan Evans, 2007).

Teori tentang cooperative security secara lebih spesifik sebenarnya merujuk pada upaya untuk membangun pengertian keamanan secara lebih luas dan timbal balik dalam upaya mewujudkan jaminan keamanan dalam jangka waktu lama lebih dari sekedar upaya untuk melakukan tindakan penangkalan terhadap ancaman pihak lawan. Karena itulah konsep cooperative security berusaha untuk mengkonstruk pemikiran sebelumnya mengenai security against adversary or enemy atau dalam upaya menjamin keamanan maka lawan harus dihadapi dengan perlawanan (menggunakan kekuatan militer) dengan pendekatan baru yang lebih bersifat security with enemy atau mengelola keamanan kawasan dengan merangkul pihak musuh atau pesaing melalui dialog keamanan multilateral. (Snyder, 1999).

Pendekatan melalui partnership security dialogue with enemy or advesary diharapkan dapat meningkatkan interdependensi dalam masalah pengelolaan keamanan kawasan serta menciptakan confidence and security-building measures $(C B M s)$ dan proses transparansi dalam kekuatan militer. Hal ini dibutuhkan agar negara-negara dalam kawasan senantiasa dapat mengartikulasikan kepentingan keamanan mereka secara bersama tanpa dilandasi rasa saling curiga namun sebaliknya bersama-sama memfasilitasi kebutuhan untuk mengelola keamanan kawasan tidak dengan menggunakan tindakan koersif atau melalui penggunaan kekuatan militer secara agresif dan provokatif. Pada prinsipnya cooperative security memfokuskan diri pada upaya untuk melindungi negara dari konflik antar negara dan juga memfasilitasi kebutuhan untuk mempertahankan status quo di kawasan maupun di dalam negara. Konsep cooperative security juga dapat digunakan untuk mengelola masalah keamanan individu maupun kelompok dalam negara. Karena itulah cooperative security juga memasukkan unsur diplomasi preventif dalam menyelesaikan masalah keamanan.

Konsep cooperative security juga mengkombinasikan komponen militer dan non-militer dalam langkah-langkah pengelolaan keamanan bersama. Karena itulah langkah-langkah dalam pelaksanaan pengelolaan keamanan kawasan dengan pola cooperative security juga mengembangkan pola multi track dialogue yang tidak saja 
melibatkan aktor negara namun juga aktor non-negara khususnya kelompok akademisi dan komunitas epistemis.

\section{Upaya Pengembangan Postur Keamanan ASEAN}

Pemahaman bahwa ASEAN adalah komunitas keamanan lebih didasarkan pada kenyataan bahwa tidak ada anggotanya yang menggunakan angkatan bersenjata atau mengasumsikan perlunya menggunakan kekuatan militer untuk menyelesaikan konflik di kawasan itu bahwa ASEAN memang komunitas keamanan karena kemampuannya. untuk mencegah konflik kemungkinan meningkatnya konfrontasi bersenjata untuk menjadi komunitas politik, adalah kenyataan bahwa tidak adanya perang antara negara-negara anggota ASEAN sejak organisasi ini didirikan pada tahun 1967 adalah pencapaian terbesar ASEAN dalam mengatur interaksi damai di kawasan ini (Leifer, 1995).

Komunitas keamanan ASEAN atau Komunitas Keamanan Politik ASEAN (APSC) pada dasarnya dibentuk sebagai upaya menjaga stabilitas kawasan Asia Tenggara. Stabilitas dan keamanan politik akan mendukung sektor ekonomi untuk menciptakan daerah yang damai dan makmur. Sebaliknya, iklim ekonomi regional yang sehat akan mendukung stabilitas politik dan keamanan karena berkurangnya kesenjangan ekonomi antar negara. Secara teoritis terlihat sederhana.Tetapi pada tingkat realitas, jalan menuju integrasi cukup curam dan berliku. Ditambah dengan fakta bahwa dalam hal apa pun, wilayah Asia Tenggara adalah wilayah yang luar biasa majemuk.

Pembentukan komunitas politik dan keamanan ASEAN merupakan fenomena yang menarik karena komunitas ini dibentuk di kawasan regional yang terdiri dari negara-negara dengan kemampuan militer yang cenderung serupa karena tidak ada hegemon regional di kawasan tersebut.

Komunitas ini diharapkan dapat mengurangi intensitas konflik dan bahkan perang terbuka antara negara-negara ASEAN. Komunitas ini dibentuk untuk menyediakan kerangka kerja regional bagi anggotanya untuk menyelesaikan masalah keamanan dan perselisihan di dalamnya dan meningkatkan dan mempercepat kerja sama ke tingkat yang lebih tinggi. Selain itu, negara-negara anggota menyadari betapa ancaman keamanan transnasional semakin berkembang yang tidak dapat diselesaikan secara sepihak. Komunitas Keamanan bertujuan untuk mempercepat kerja sama politik keamanan di ASEAN untuk membawa perdamaian ke kawasan, termasuk dengan komunitas internasional. Komunitas ini terbuka, berdasarkan pendekatan keamanan yang komprehensif dan tidak dimaksudkan untuk membentuk pakta pertahanan / aliansi militer atau gabungan kebijakan luar negeri. Komunitas ini juga mengacu pada berbagai instrumen politik ASEAN yang telah ada Forum Regional ASEAN (ARF) dengan tiga pilarnya: membangun kepercayaan (CBM), diplomasi preventif (Preventive Diplomacy), dan resolusi konflik (resolusi konflik), Zona Damai, Kebebasan dan Netralitas (ZOPFAN), Perjanjian Amity dan Kerjasama di Asia Tenggara (TAC), dan Perjanjian tentang Zona Bebas Senjata Nuklir Asia Tenggara (SEANWFZ), dan mematuhi Piagam PBB dan prinsip-prinsip hukum internasional lain yang relevan. 
Terlepas dari hambatan terhadap komunitas keamanan, peluang ASEAN untuk sepenuhnya terintegrasi terbuka lebar. Itu politik keamanan masyarakat masih bisa terwujud meski di antara negara-negara anggota masih mempertahankan kultus masing-masing. Perselisihan antar negara di kawasan Asia Tenggara tidak terhindarkan. Tingkat keanekaragaman yang tumpang tindih dan kepentingan antar negara yang mengarah pada konflik adalah biasa. Tetapi politik dan keamanan masyarakat tidak memerlukan hilangnya konflik ini. Alih-alih menghilangkan konflik, ini masyarakat mengacu pada kemampuan untuk mengelola konflik secara damai. Sehingga format ASEAN di masa depan adalah bagaimana negaranegara anggota ASEAN memperlakukan instrumen perdamaian secara sah.

Kesiapan ASEAN dalam komunitas ini tidak ditentukan oleh keberhasilan delegasi negara-negara anggota yang menandatangani Deklarasi Bali Concord II pada tahun 2003, itu hanya akan menjadi simbol konsensus di atas kertas jika tidak diaktualisasikan dalam bentuk aksi nyata. Selain itu, kesiapan ASEAN untuk membentuk sebuah komunitas ditentukan oleh proses ASEAN dalam menyelesaikan konflik secara damai antara negara-negara anggotanya sesuai dengan instrumen multilateral yang ada.

Itulah pembentukan komunitas politik dan keamanan ASEAN tidak keputusan tergesa-gesa. Membentuk komunitas tidak sesederhana konsepnya. Mendirikan politik dan keamanan masyarakat terdiri dari negara berdaulat membutuhkan pengorbanan dan konsistensi. Jadi itu tidak berasal dari tren regionalisme yang menjadi ciri khas sistem internasional saat ini. Keberhasilan Uni Eropa dalam menciptakan komunitas bersama tentu tidak dapat digunakan sebagai cetak biru untuk pembentukan ini masyarakat karena konteksnya sangat berbeda. Asia Tenggara masih membutuhkan waktu lama untuk mengubah keegoisan menjadi keinginan bersama.

Proses pembentukan identitas kolektif ASEAN tidak hanya terbatas pada " Asean Way" norma sebagai dinyatakan dalam Deklarasi Bangkok. Identitas kolektif ASEAN akan dilihat dari seberapa besar kemauan negara-negara anggota untuk memperlakukan ASEAN sebagai suatu Kode etik atau aturan main dalam hubungan internasional di Asia Tenggara, khususnya yang berkaitan dengan dimensi keamanan regional. Jadi kuncinya di sini adalah latihan, bukan konsepnya. Jika tidak, komunitas keamanan ASEAN hanya de jure karena secara de facto masih tidak dapat mengimplementasikan aturan yang disepakati sendiri.

Harapan bahwa ada prospek cerah bagi ASEAN dalam mewujudkan Komunitas Politik dan Keamanan adalah tentu sangat diharapkan, tetapi berbagai kendala pasti ada. Pada dasarnya, sejak awal, pembentukan ASEAN jauh berbeda dengan Uni Eropa di level heterogenitas dihadapi, 10 negara Asia Tenggara memiliki beragam keanekaragaman di bidang budaya, ras, agama dan dipengaruhi oleh berbagai kekuatan dan berbagai tingkat pertumbuhan ekonomi, dan berbagai pandangan politik dan ideologis dan ini disebut sebagai kelompok budaya, terutama masyarakat Asia Tenggara tidak terbiasa menjadi satu. 


\section{SIMPULAN}

Berdasarkan paparan di atas bahwa terlihat bahwa pembangunan keamanan ASEAN bisa bisa dikatakan efektif. Karena negara-negara sangat menjunjung tinggi nilai ASEAN Way yaitu prinsip non-intervensi.

\section{DAFTAR PUSTAKA}

Adler, Emanual. (1998). Michael Barnet A Framework For The Study of Security Communities. New York: Cambridge University Press.

Assesment. (2014). Key Development and Trend in Asia-Pacific Security 4.

An ASEAN, of The People, by The People, for the People", Report of the First ASEAN People's Assembly, ASEANISIS-CSIS, Batam, Indonesia, 24-26 November 2000.

Bellamy, Alex J., and Matt McDonald. (2004). Securing International Society: Towards an English School Discourse of Security. Australian Journal of Political Science 39, no. 2 (2004): 307-30, doi:10.1080/1036114042000238537

Buzan, Barry. (1991). People, State and Fear: An Agenda for International Security Studies in the Post Cold War Era 2nd Edition. New York: Harvester Wheatsheaf.

Capie, David dan Evans, Paul. (2007). The Asia-Pacific Security Lexicon. Singapore: Institute of Southeast Asia Studies.

Deustch, Karl. (1969). Political Community and The North Atlantic Area: International Organization in The Light. New York. Greenwood Press Publisher.

Leifer, Michael. (1995). ASEAN as a model of a security community?, dalam Hadi Soesastro (ed.), ASEAN in a changed regional and International Economy. Jakarta: CSIS, 1995.

Nugraha, F. (2012). Cikal Bakal Konflik Laut China Selatan Dipetik Mei 13, 2017, dari Okezone: http://news.okezone.com/read/2012/08/17/411/679284/cikalbakal-konflik-laut-china-selatan

Runtukahu, M. A. (2009). Peran Indonesia dalam Proses Penyelesaian Konflik Kamboja (Periode 1984-1991). (Tesis). Fakultas Ilmu Sosial dan Ilmu Politik, Universitas Indonesia, Depok. 
Sari, K. (2008). Thailand dan Kamboja Tambah Tentara di Perbatasan. Jakarta.http://kompas.co.id/read/xml//.

Snyder, Craig A. (1999). Contemporary Security and Strategy. London: Deakin University.

Soderbaum, Fredrik dan Grant, J. Andrew. (2003). The New Regionalism in Africa. London: Ashgate Publishing.

Vesa, Unto. 1999. Prospects of Security Communities: On The Relevance of Karl W. Deutsch's Contibution', Peace Research, 31(1) (Feburari 1999): 18-25. 